\title{
Life post-closure: perception and use of rehabilitated mine sites by local communities
}

\author{
K Svobodova The University of Queensland, Australia
}

\begin{abstract}
The social dimensions of resource extraction have always presented a major challenge for industries. This is particularly acute towards the end of the project lifecycle when multiple pressures align. Planning for successful mine closure is a key driver in the mine design, planning and the sequencing process. This enables the mine to be progressively rehabilitated towards a well-understood and acceptable final landform and land-use outcome. Although a significant need to better understand the social aspects of mine closure has been recognised across the industry, there is a lack of case studies that cover the long-term post-closure outcomes. Without case study material, it will not be possible to develop realistic guidance for closure practitioners considering social and community aspects. The guidance is particularly important in densely-populated regions where open pit mines frequently overlap with sensitive ecosystems and with intangible cultural values. The study investigated how people living in close proximity to open pit mines and mine rehabilitation sites perceive their neighbouring landscapes and how they use the post-mining land in their everyday lives. A total of 40 residents from two communities in a lignite-mining region in the Czech Republic were interviewed. While one community is living adjacent to a closed mine site, the other is next to an operating mine with closure planned in 20 years. The relationship between communities and the postmining and mining sites, as well as to the mining company operating in the area were investigated. Participants identified places that they use in their everyday activities and places with various cultural and natural values and meanings. The results show that most respondents use post-closure landscapes in their leisure time activities and appreciate their high aesthetic, recreational and natural values. Place attachment, feelings of belonging, experience of positive results of mine rehabilitation, and economic benefits played a key role in the communities' perception. The study introduced a spatially-explicit qualitative approach that can assist in maximising the beneficial use of post-mining land, in particular to evaluate the restoration success of post-mining sites.
\end{abstract}

Keywords: mine closure, social impact, community engagement, relinquishment

\section{Introduction}

A growing global movement towards emission reduction is driving an agenda focused on alternative energy solutions. The European Parliament has called for the European Union (EU) to cease using coal for energy production by 2030 and supports the member states to incorporate this timeline in their energy policies. The implications of this transition will be substantial for mining regions. A rapid and widespread closure of coal mining projects is expected in order to meet legal demands for a low carbon future. It will give rise to major disruptions to regional economies, demographics and social organisation of coal mining regions. To achieve long-term sustainability and social gain in these regions, effective mine closure planning is becoming an important current issue in development of the regions.

Mining regions are characterised by a lack of economic diversity, demographic instability, increasing health issues, geographic isolation, dependence on the mining companies, and the absence of alternatives for diversified economic development (Bebbington \& Bebbington 2018; Frantál 2016). Petrova \& Marinova (2013) spoke about the culture of transiency and dependency. The advent of a large mining operation is often envisaged by local communities as an opportunity to provide resources and infrastructure, as well as to improve the quality of life and living standards. This type of expectation increases community dependence 
on depleting assets that a community is not in a position to establish. On the other hand, a phenomenon of transiency includes population mobility and transient workforce, with consequences to a local social landscape such as imbalance within the local population structure and contributing to lower social capital.

A defining feature of communities living in close proximity to mine operations is the pattern of cohabitation between a mine and a community (Owen \& Kemp 2015). These communities are characterised by the complexity of relations inside a community, between a community and a mine, and between a community and an operating company. Due to the proximity to the operations, the communities have witnessed dramatic changes in their nearby landscapes, accompanied with direct and indirect environmental, health, and socio-economic impacts. This can cause tension inside the communities such as disruption to social structures and community networks, the loss of traditional cultural ties, local identity and place attachment, but also uncertainty connected with possible future disruption and dislocation (Frantál 2016). These aspects significantly shape the community's feeling of wellbeing and their satisfaction with the life in a mined land, with consequences for their acceptance of mining operations and the mining company itself (Owen \& Kemp 2018). Individual and community perception can particularly create a fundamental challenge for mine closure as shown by Zvarivadza (2018). To enable the mine to be progressively rehabilitated towards locally acceptable final land-use, it is important to understand the community perception of long-term post-closure outcomes and the values that people associate with post-mining landscapes. This is particularly important in densely-populated regions where large open pit mines frequently overlap with sensitive cultural values. These values refer to the meanings such as people's perceptions and past experiences, history, culture, and traditions that are attached to particular places (Cresswell 2004). The way in which people relate to place affects how they express what they value and the qualities of life that they value (Geertz 1996). Amundsen (2015) argues that people are committed to their place and act to improve the image of their communities and to create activities on the basis of an emotional connection to the place. In this way, place attachment might determine the success or failure of any planning efforts on a community level (Agyeman et al. 2009), including mining projects.

This study aims to investigate how people living in close proximity to an active open pit coal mine and mine rehabilitation sites perceive the sites. The goal is to explore their attitudes towards these sites, as well as their relationships with their community and the mining company. The particular interest lies in how these perceptions differ between the two communities in relation to mine closure and successful relinquishment. Using participatory value mapping, the spatial extent of the perceptions was identified to capture values and meanings that residents associate to particular places in their close neighbourhoods.

\section{Geographical, legal, and historical context of the study}

The Czech Republic, formerly Czechoslovakia, was part of the Eastern Bloc from 1948 to 1989. As a member of the former Comecon group of countries with a command economy, Czechoslovakia shared a common ideology and resources under complete governmental control of the Soviet Union. Coal was regarded the national 'black gold' of a centrally-controlled dominance of metallurgical and energy-intensive heavy industries (Frantál 2016). In that period, the production of lignite as the main source of energy increased about five times and electrical power generation about 20 times (Czech Statistical Office 2012). The rapid increase lead to enormous changes in the scale of open pit mining and resulted in permanent changes of the environment and the land topography as shown by Hendrychová \& Kabrna (2016). As communist planners continually increased energy and coal production between the 1950s and 1970s, the surface mines and constructions of related thermal power plants lead to destruction of over 100 villages and towns, and resulted in resettlement of about 90,000 residents (Říha et al. 2005). After the fall of communism in 1989, the newly-established democratic government prepared programs to restore the environment and to create a balance between economic, social, and ecological interests of the state and coal regions. Lignite mining has been significantly reduced and intense large-scale reclamation has been progressively applied. With the growing number of well-established reclamation projects, the natural values in coal regions have been increased (Hendrychová \& Kabrna 2016). 
The Czech Republic is heavily dependent on coal for its energy needs and relies mostly on domestic reserves of lignite that include eight active open pit mines located in two mining regions. The annual production of lignite was 39.3 Mt in 2017, with most of this being used for electricity production (31.3 Mt). Production came from three companies: 70\% state-owned Severoceske Doly (SD) (21.7 Mt) and two private companies called Sokolov Mining (SM) (6.9 Mt) and Sev.en Group (10.7 Mt). In 2017, the mix of electricity sources was dominated by lignite (42.5\%) and nuclear (32.5\%), followed by hard coal (5.2\%), gas (3.9\%), and other sources (15.9\%). According to the State Energy Policy (Ministry of Industry and Trade 2014), coal will remain the country's primary energy source in the future. The government expects coal to account for $30.5 \%$ of energy production in 2030 (European Association for Coal and Lignite 2018), despite the EU's call for exit coal by that year.

According to the national legal framework (Czech Republic 1988), all coal deposits are exclusively owned by the state. When mining companies lease the land above the deposits, they must pay an annual rent to the state and to the landowners. To compensate for the direct impacts of mining, the state transfers approximately $35 \%$ of the rent to the municipalities affected by mining. In addition, all areas affected by mining activities have to be rehabilitated, and the cost of rehabilitation must be completely covered by mining companies. To guarantee quality of mine rehabilitation, mining companies pay a fee from every tonne of excavated coal to a special bank account owned by the state, under the supervision of the National Mining Council (NMC). The fee is calculated before the commencement of mining, as part of the licencing application process. Calculation of the fee is based on the size of deposit and the extent of planned rehabilitation works. The NMC conducts annual onsite reviews of mine rehabilitation outcomes. If these outcomes are found to be acceptable, the council releases money for the company to continue with rehabilitation planned in the next year.

\section{$3 \quad$ Methods}

\subsection{Study area}

The study investigated two communities located in the Sokolov lignite coal basin, namely Habartov and Lomnice (Figure 1).

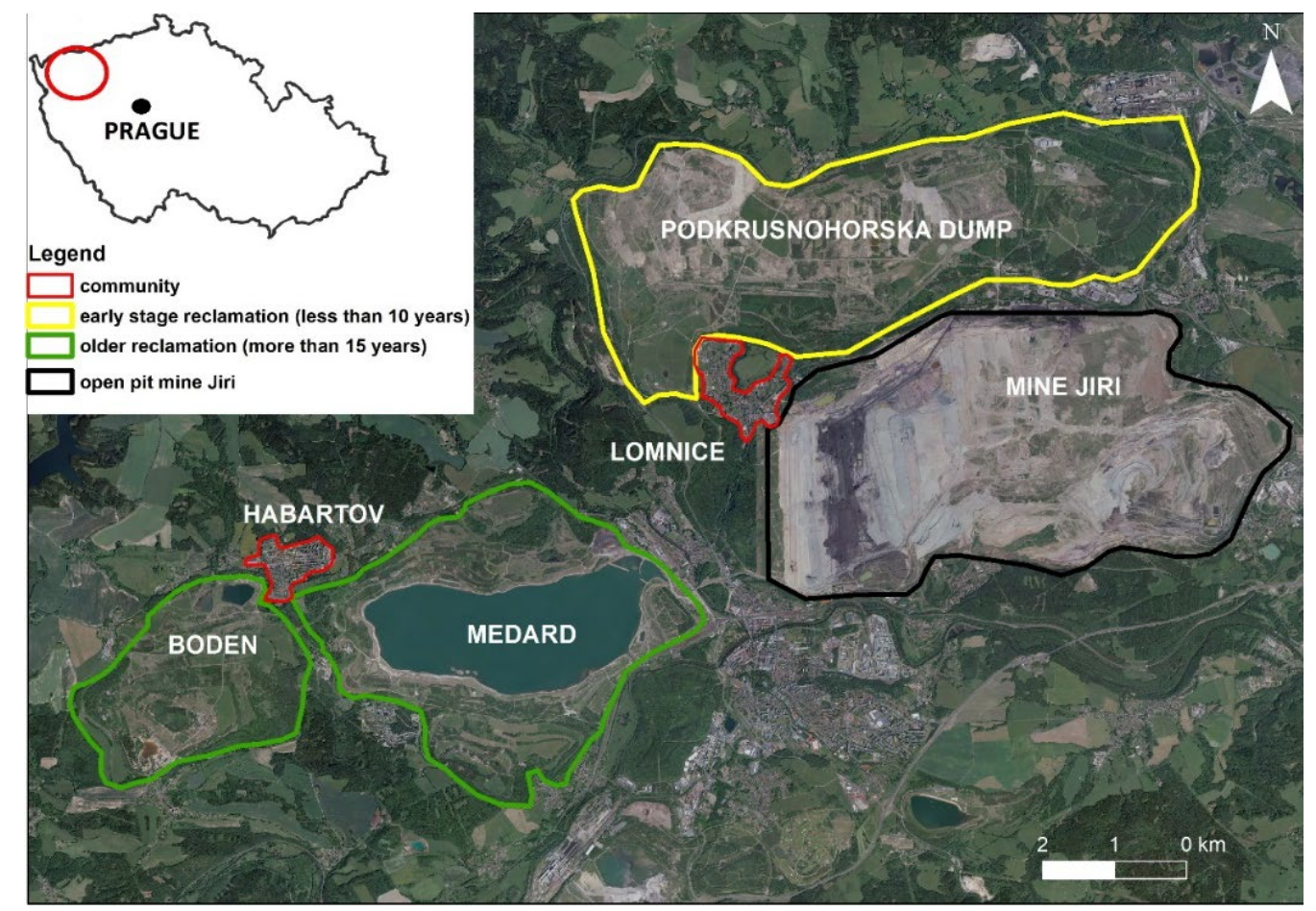

Figure 1 The location of the study area. The communities of Habartov and Lomnice lie in close proximity to the Boden, Medard, and Podkrusnohorska dump rehabilitation sites, and to the Jiri open pit mine (adapted from ArcGIS 2019) 
While Habartov lies in the heart of about 20-30-year-old mine rehabilitation including pit lakes and forests, Lomnice is surrounded by ongoing mining and reclamation works. The SM company that operates all lignite mines in the study area was privatised to a joint-stock private company in 2005. The company is the smallest lignite mining company in the Czech Republic in terms of workforce, and the second biggest producer of electric energy in the country.

The population of Habartov is about 5,000 people. More than half of the town's cadastre $\left(11.16 \mathrm{~km}^{2}\right.$ out of $21.39 \mathrm{~km}^{2}$ ) still remains under the lease of the SM company. The former town was destroyed due to mining in 1950s and residents were resettled to a newly established town nearby the previous town for which construction was completed in 1976. Habartov is located close to the Boden and Medard pit lakes and the Litov waste dump. The dump covers a total area around $7 \mathrm{~km}^{2}$ (Figure 2). The Boden mine was closed in 1992 to be rehabilitated to a lake and forests. The Boden pit lake is suitable for fishing and swimming. The rehabilitation site includes facilities such as inline tracks, golf, and volleyball and tennis courts built by the Habartov council. The Medard lake pit with a total area of $5 \mathrm{~km}^{2}$ started to fill up with water in 2000 . The current use of the lake is mainly for water sports and swimming.

Lomnice has a population of 1,300 people. The SM company operates on $9.18 \mathrm{~km}^{2}$ out of $13.12 \mathrm{~km}^{2}$ of the town's cadastre. The municipality has remained, and will continue to remain, in its original location and at its original size. It lies between the Jiri open pit and its Podkrusnohorska waste dump (Figure 2). The mine has been operating since 1981 with an annual production of $8 \mathrm{Mt}$. The mine is planned to be closed in 2035 and rehabilitated to a pit lake. The Podkrusnohorska dump has been reclaimed to forests with a total area of $19.57 \mathrm{~km}^{2}$ and at a height of $120 \mathrm{~m}$. Around $800 \mathrm{Mm}^{3}$ of overburden was deposited in the dump from 1960 to 2003. Most of the dump is not publicly accessible due to ongoing reclamation works.

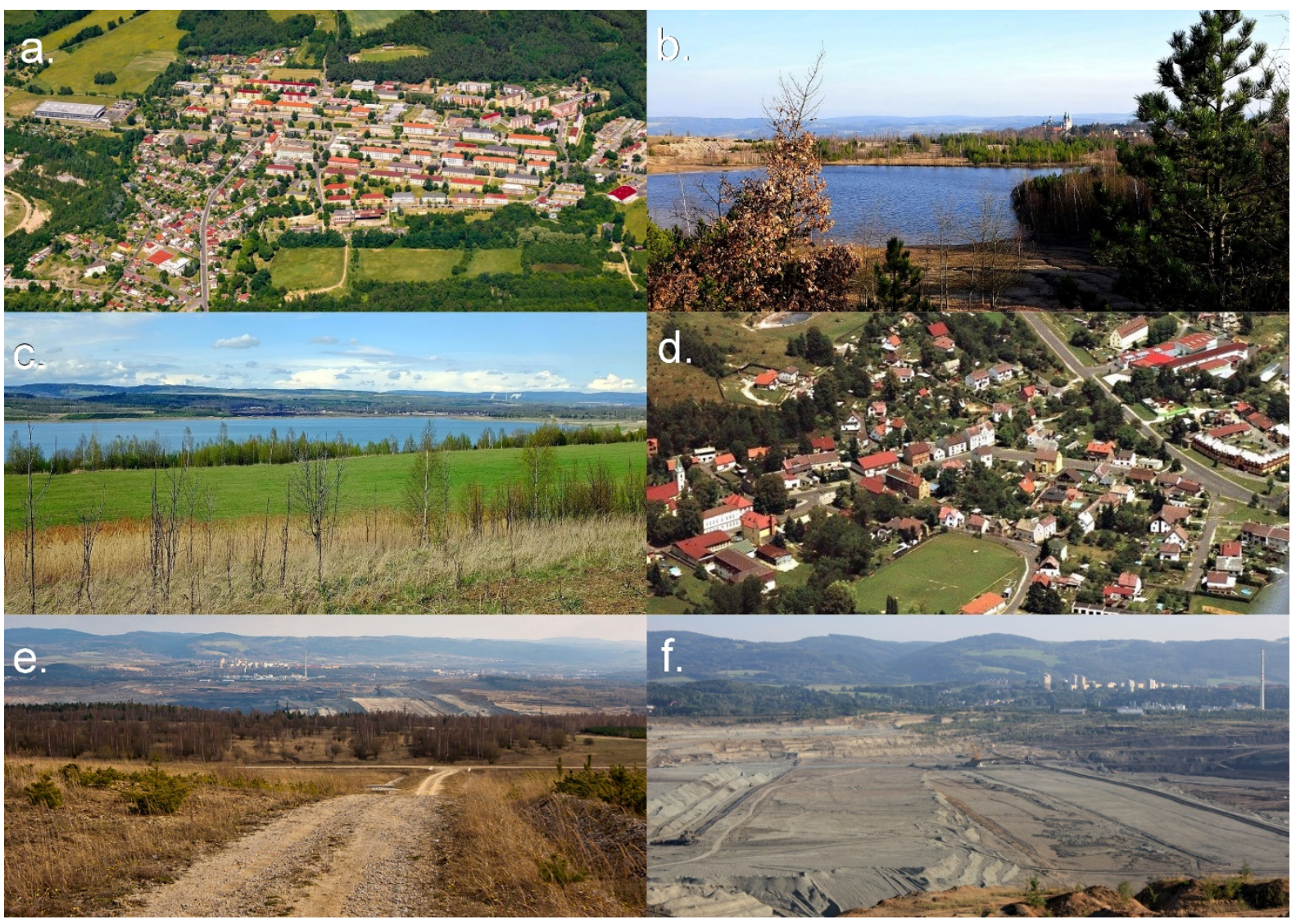

Figure 2 The Habartov and Lomnice communities and their surrounding landscape features: (a) new relocated town of Habartov; (b) Boden pit lake; (c) Medard pit lake; (d) town of Lomnice; (e) extensive Podkrusnohorska dump with continuing reclamation work; (f) Jiri open pit mine 


\subsection{Data collection and analyses}

The study utilised qualitative methods including face-to-face semi-structured interviews and participatory value mapping. Forty interviews with residents from the communities of Habartov and Lomnice were conducted (20 interviews per community). The interview comprised of three parts. During the first part, respondents were asked about life in the municipality and about the unity of the community. During the second part, the focus was on the interviewees' attitudes towards the mining company and their perception of mining and post-mining sites. The third part aimed to gain spatially explicit information on how community members perceive and experience the local landscape, how they use the environment, and what cultural and natural values they associate with particular places. For this study, a method of participatory value mapping was applied, using printed topographic maps and colour pencils (red=positive, black=negative, green =neutral). Respondents were asked to identify places of their daily activities (= neutral); places with high aesthetic and natural values, those important for future of the community, and localities where they relax (= positive). Participants also identified places with negative values and meanings such as scary and dangerous places, places that are destroyed by human activities, and those that need remediation (=negative).

When selecting respondents for the interviews, the focus was on adult residents who have spent at least 10 years in the community and who had different levels of education and different occupations. The interviews were conducted between January and March 2017. The interviews took approximately one hour and were recorded and transcribed. To analyse the transcripts, open coding was used, including labelling and defining categories for every topic. The respondents' value maps were scanned and manually transferred in ArcGIS (Environmental Systems Research Institute 2018) to shapefile formats. To identify overlapping values, potentially conflicting places, and community 'hot spots', overlay analysis was applied by using tools such as Union and Intersect (Environmental System Research Institute 2016). All information provided by the respondents was treated as strictly confidential. The respondents received codes such as HAB001 (i.e. an interviewee number 1 from Habartov) or LOM001 (i.e. an interviewee number 1 from Lomnice).

\section{$4 \quad$ Results and discussion}

\subsection{Participants}

Forty participants, consisting out of 20 men and 20 women, were interviewed. Of those, $45 \%$ had always been living in the community and had therefore possessed long-term experience with landscape changes and their local knowledge of the area was high. A total of 33\% of participants worked for the SM company. The characteristics of the respondents are shown in Table 1.

Table 1 Characteristics of 40 respondents participating in the study

\begin{tabular}{lll}
\hline Characteristics & Habartov & Lomnice \\
\hline Average age & 49 years & 48 years \\
Education & University 6 & University 2 \\
& High school 9 & High school 13 \\
& Lower 5 & Lower 5 \\
Average time spent in the community & 43 years & 40 years \\
Number of employees of the mining companies & $5(25 \%)$ & $9(45 \%)$ \\
\hline
\end{tabular}




\subsection{Perception of the community, familiarity, and belonging}

The results showed that residents of both communities had very strong and familiar relationship with their municipalities and its surroundings. All participants wanted to stay and live in their town in future. Residents of Habartov particularly emphasised aesthetic and natural values. They all perceived their town as close to nature. For example, one interviewee from this town commented, "I look out of the window and when I see it, I think...someone would not say that there was mining before. It is just beautiful, so beautiful. The nature is all around" (HAB001) while another commented, "I'm happy here, the nature nearby is important for me. If I go out of my house, I'm immediately in forests" (HAB002).

Although Lomnice community members were concerned about negative impacts of mining such as dust, noise, light from excavators, and landscape destruction, they considered these effects as a cost of economic and employment benefits provided by the mining company. One of the interviewees said that:

"Of course the pit is an ugly hole in the ground, a mess. Nothing very enjoyable. But it's part of our landscape here. There is nothing what we can do about it. I feel that people need to work. Coal is needed and when I decided to live here, it is just part of my life. That's it." (LOM007)

All participants from Lomnice showed deep feelings of belonging and believed in the comeback of green landscape after mine closure. For instance, it was stated that:

"Lomnice is everything for me. We go out for walks to the waste dumps and I look forward to seeing that in 10 years - I hope I will be still alive - the pit will be closed or coal will be excavated further away from Lomnice. Here, it will be reclaimed and it will become green again." (LOM010)

The values that residents perceived as important in their community and their concerns are summarised in Figure 3.

Good facilities and infrastructure

Many green areas and tidiness

Variety of leisure time activities

Convenient location and size

Proximity to nature

Beautiful town

Familiarity and place attachment
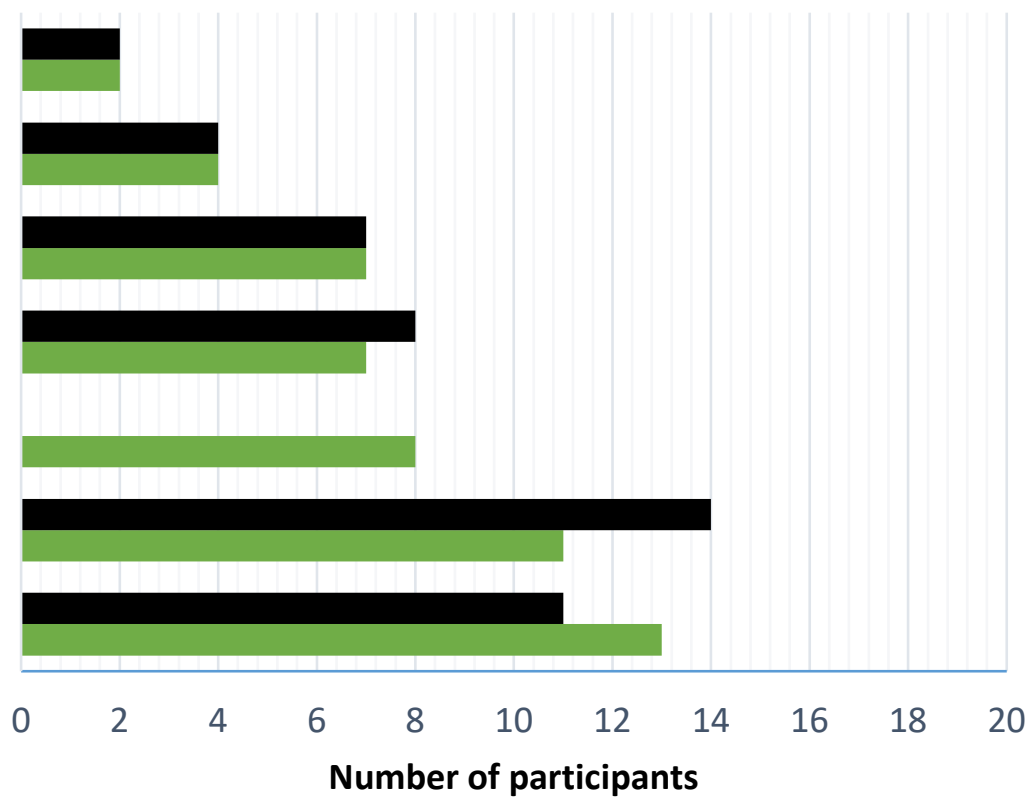

Number of participants

Lomnice Habartov

(a) 
Coal mining - dust, noise, light pollution

Untidiness in the town

Unbalanced population structure

Insufficient facilities and infrastructure

"not really negative but I know better places to live"

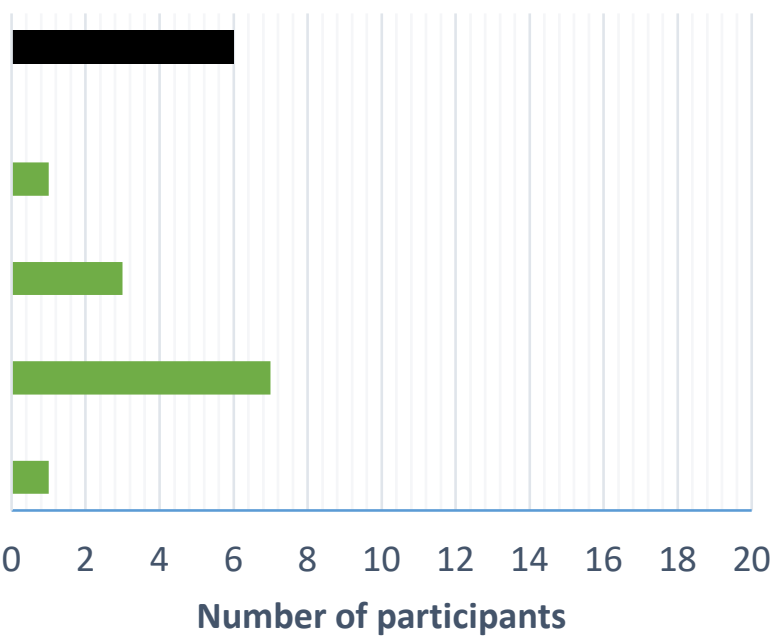

Lomnice Habartov

(b)

Figure 3 Opinions of respondents on (a) values and (b) concerns in the communities of Habartov and Lomnice

\subsection{Attitudes towards the mining company}

Participants exhibited both positive and neutral attitudes towards the SM company. They mainly enjoyed economic benefits for the region or their personal income from current or previous employment by the company. The participants did not have negative opinions about the company.

In Habartov, 15 residents (75\%) showed positive attitudes towards the company. Five from a total of 20 were employed by SM at the time of the study and indicated their positive attitude by saying, for instance, "My opinion about the Sokolov Mining is positive since the company has great credit here. I mean here in the region" (HAB012) or "I feel positively about Sokolov Mining because our family has been working there all our lives" (HAB009).

Five participants (25\%) described their attitudes towards the company as neutral. None of them worked for the company, with one of these stating, "I would say that my perception of the company is neutral. I don't work there" (HAB008).

Residents of Lomnice were even more positive in their judgements. Three participants (15\%) had a neutral opinion about the company with 17 (85\%) showed positive attitudes. One of those with a neutral opinion stated that:

"... I would probably choose the neutral way. First, I think the good thing is that people have jobs. On the other hand, it is an interference with the nature that damages it. When I was a little girl, there were forests. It was possible to go to nature, we had many choices, nothing like now. They rehabilitate the land, which is good, but it is still a huge destruction. The village that was nearby, has completely disappeared. I remember the village. People lost their houses, although they got a substitute, but they certainly had a relationship to the land there, and they had to leave everything due to mining... So I would say my relationship to the company is more or less neutral." (LOM013)

17 community members (85\%) showed positive attitudes, with one saying:

"... well, I have either very positive or positive attitude towards the Sokolov Mining. We all have jobs here. In a way as a citizen I understand that the dust ... It does not bother me so much, since we live further from the pit, on the opposite site of the town. On the 
other hand, I think that we profit by a lot of positives that are behind the negatives, so I think I would say I have a very positive attitude." (LOM005)

\subsection{Perception of the mine and mine rehabilitation sites}

While the Habartov community interviewees talked about the temporary nature of mining, emphasising benefits of mine reclamation, a negative perception of the Jiri open pit was apparent across all participants in the Lomnice community. Although they considered coal mining as an important part of their local economy, they all felt the mine was a disturbing omnipresent element in the community. This was evident in their comments. One interviewee stated that:

"Dust and noise are enormous here. My property is losing its value and we are losing money. I understand that the pit is a necessary evil because of the jobs here, but on the other hand, it bothers me so much." (LOM008)

Some interviewees felt nostalgia for the former landscape that was there before mining, but some interviewees were apathetic about the Jiri open pit, with one stating that:

"Daddy told me that it was beautiful there, that they used to go there to swim and to camp. My grandma talks about the area very nicely too. I perceive the pit as a hole, dust and noise. I realise that it provides a lot of work for people here, but I don't care about the pit. I have no interest in mining." (LOM001)

Similar apathy regarding to active mines was recorded in the Habartov community in relation to the former Boden pit. One of the interviewees stated that:

"I remember Boden before mining. It was a beautiful area. We used to go there for walks with our kids. A forest, a small lake and a football field were there. Nature was beautiful there. Then mining started. Since that, I don't remember much. We stopped going there. We were no longer interested in that area. There were trains with coal. It was dusty. Now, Boden is reclaimed and it's beautiful again." (HAB008)

In contrast, two residents of Lomnice pointed out the uniqueness of their community related to its location at the edge of the Boden pit, with one stating, "When friends or relatives arrive to Lomnice, I take them to the viewpoint to have a look at the pit. They are crazy about it. The pit is sort of an attraction here" (LOM007).

Overall, both communities perceived reclamation and post-mining sites very positively. For example, an interviewee from Habartov stated that:

"It doesn't seem to me that the area is different now. The forests, meadows. It all looks pretty good. Trees are already growing there. It is not very different from other areas that had not been mined." (HAB009)

Both communities used mine rehabilitation sites for a variety of leisure time activities as shown in Figure 4. 


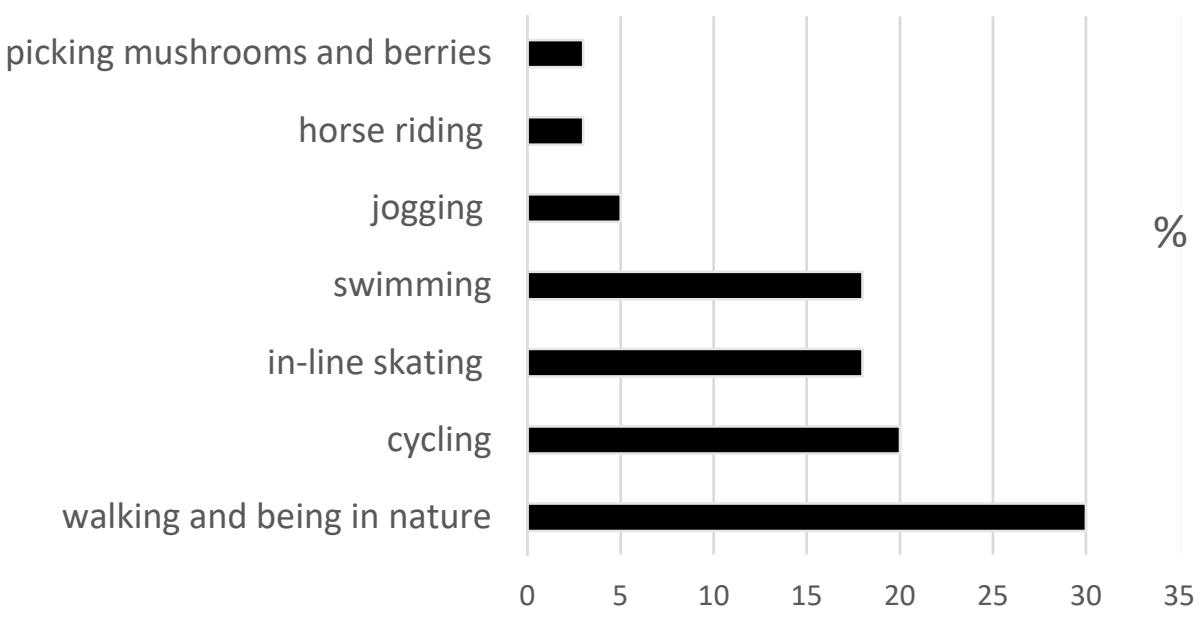

Figure 4 Leisure time activities conducted in mine rehabilitation sites by surveyed communities

In terms of spatial distribution of participant's perception of mining and post-mining sites, participants identified various aesthetic, natural, and recreational values in all post-mining sites without any difference between the new and old mine rehabilitation sites and their accessibility, as shown in Figure 5 . In terms of future development of the community, while the Habartov community saw both pit lakes as important, the Lomnice community did not consider the Podkrusnohorska dump as important for their future. On the contrary, across all participants, negative values such as 'dangerous' or 'destroyed' were associated with the active Jiri mine as shown in Figure 6.

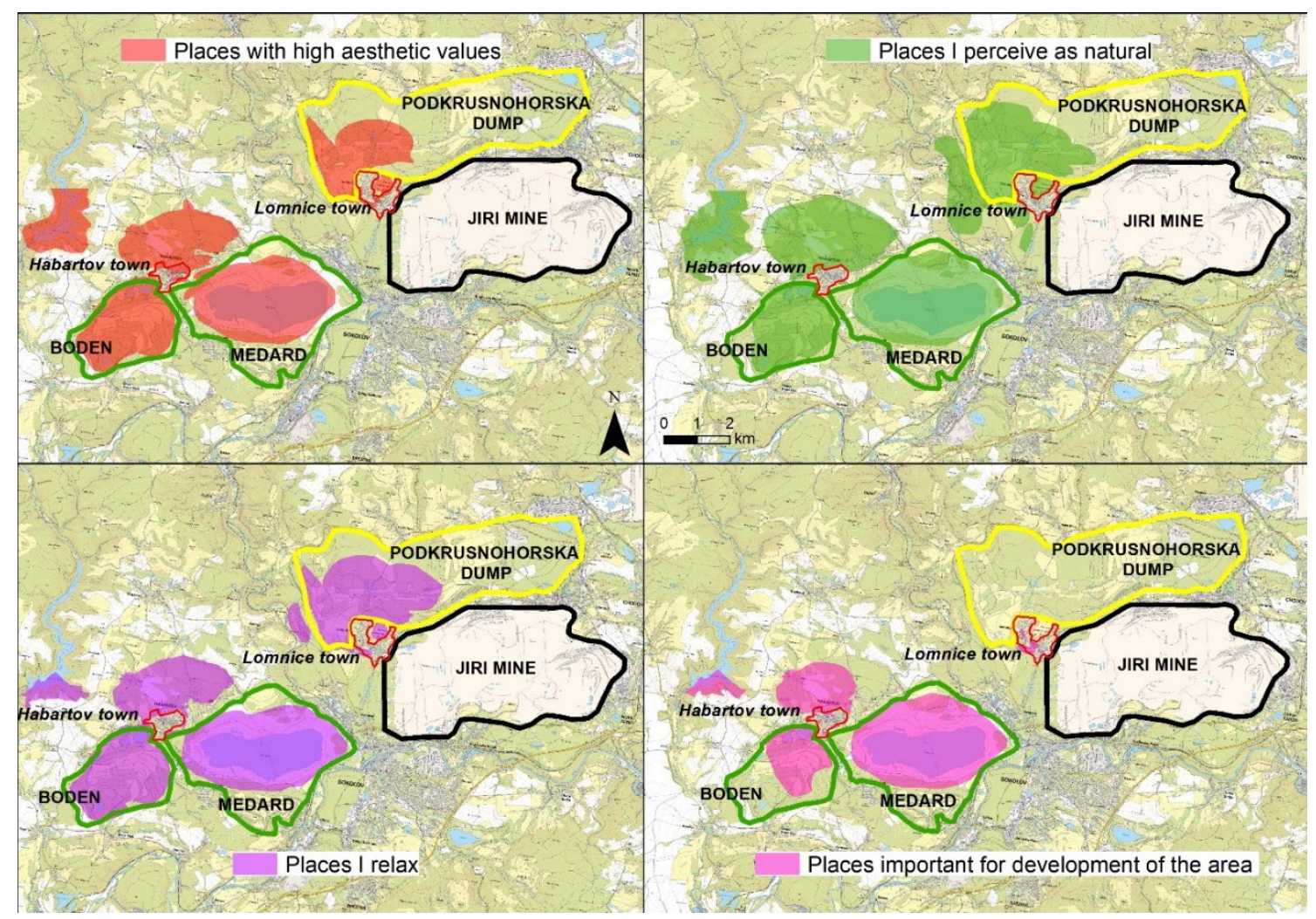

Figure 5 Values and meanings associated with local landscapes. All positive values were identified in the reclamation sites or surrounding natural areas (adapted from Geoportal CUZK 2019) 


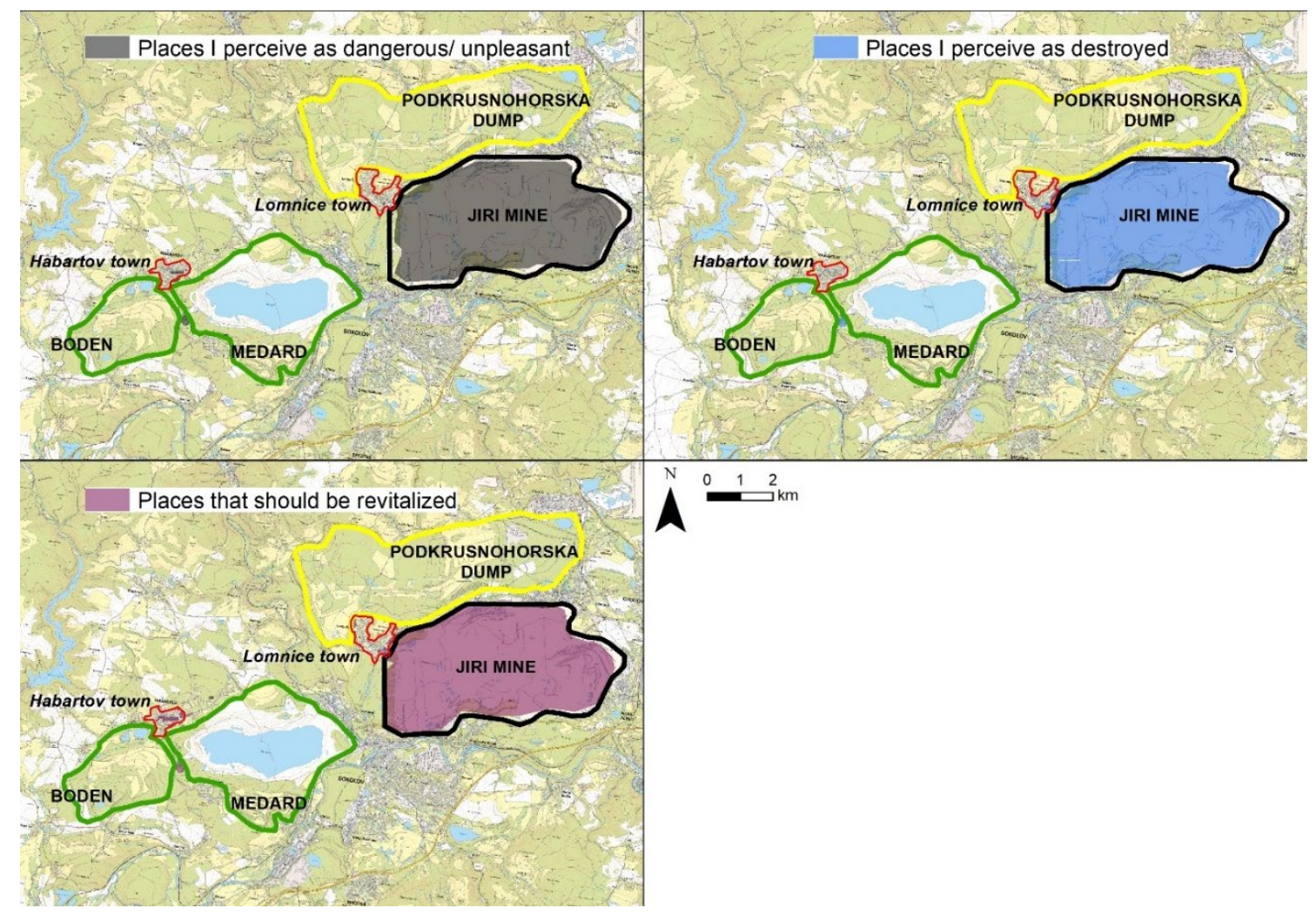

Figure 6 Concerns associated with local landscapes were exclusively connected with the Jiri open pit (adapted from Geoportal CUZK 2019)

\section{Conclusion}

The final milestone in the life-of-mine cycle arrives when decommissioning, closure, rehabilitation, and post-closure activities are completed. Globally, the success of rehabilitation of post-mining sites range from abandoned unreclaimed mines to carefully planned post-mining landscapes. This study shows an example of two communities located in the heart of a coal mining region in the Czech Republic. One community benefits from completed closure and mine rehabilitation while the other one deals with disturbing direct impacts of continuing coal mining and reclamation works. The study is framed by the complex history and socio-economic situation as consequences of a centrally controlled economy in the former Eastern Bloc of Europe.

The results show that most respondents are satisfied with the post-closure outcomes. In particular, the Lomnice community has positive expectations about closure of the Jiri mine to the conditions of other post-mining sites in the region. The study found that place attachment, feelings of belonging, experience of positive results of mine rehabilitation, and economic benefits play a key role in the community's perception of their life in a mined land. Although community members witnessed negative changes of their surroundings, they defended the place against criticism of its location in close proximity to mining, motivated by the future values after mine closure and relinquishment.

Participants showed strong place attachment to their communities. Although the Lomnice community experiences adverse impacts of mining such as dust, noise, and light pollution, they hope in a better future and positive mine rehabilitation outcomes. This concurs with Amundsen (2015) who showed that communities committed to their place act to improve the image of the place in an emotional way.

Economic benefits for the community were anticipated by nearly all respondents in both communities. They had generally positive opinions on the mining company. This confirms the concept of interdependency between mining and local communities as previously discussed by Owen \& Kemp (2015). The history of the mining company's operations in the area was also a very important factor in the development of community 
perception as previously shown by van der Plank et al. (2016). Although the SM company has been privatised, the same practice, particularly the way of communication and collaboration with communities, remains.

The findings from participatory value mapping showed that both communities considered mine rehabilitation sites as valuable and promising in future while the Jiri open pit had exclusively negative connotations. None of the respondents considered the Jiri pit or the new Podkrusnohorska dump as important for future development of the community, but interviews revealed the apparent economic benefits from mining. In terms of using the post-mining sites, the results showed that proximity and accessibility play a crucial role. For instance, the Podkrusnohorska dump, despite her early stage of development, has been used as a place where locals go to relax. The dump is perceived as a natural and beautiful place in close proximity to the Lomnice community. Similarly, facilities such as playgrounds and sport areas, for example, around the pit lake Boden, were identified as an important factor motivating locals to use the post-mining sites in their everyday leisure activities.

The study utilised a spatially-explicit qualitative approach that can assist in determining ways to maximise the beneficial use of post-mining land. This can contribute to development of adaptive strategies in closure planning that are responsive and relevant to community needs and expectations. Moreover, participatory value mapping enables us to identify locations with potential future land use conflicts, to communicate the impacts of mining, and to evaluate the restoration success of post-mining sites.

\section{Acknowledgement}

I would like to thank Josef Janura who greatly assisted in data collection and interviews. I also wish to thank Professor John Owen for his constructive advice and suggestions.

\section{References}

Agyeman, J, Devine-Wright, P \& Prange, J 2009, 'Close to the edge, down by the river? Joining up managed retreat and place attachment in a climate changed world', Environment and Planning A, vol. 41, pp. 509-513.

Amundsen, H 2015, 'Place attachment as a driver of adaptation in coastal communities in Northern Norway', Local Environment, vol. 20, pp. 257-276.

ArcGIS 2019, World Imagery, viewed 30 March 2019 https://www.arcgis.com/home/item.html?id=10df2279f9684e 4a9f6a7f08febac2a9

Bebbington, A \& Bebbington, HD 2018, 'Mining, movements and sustainable development: Concepts for a framework', Sustainable Development, vol. 26, no. 5, pp. 441-449.

Cresswell, T 2004, Place: A Short Introduction, Wiley-Blackwell, Hoboken.

Czech Republic 1988, Zákon č. 44/1988 Sb., o ochraně a vyusití nerostného bohatství [Act No. 44/1988, on the protection and utilisation of mineral resources].

Czech Statistical Office 2012, Historická ročenka statistiky energetiky - 2012 [Historical Yearbook of Energy Statistics - 2012], viewed 28 March 2019, https://www.czso.cz/csu/czso/historicka-rocenka-statistiky-energetiky-2012-1cnxjg29ai

Environmental System Research Institute 2016, Overlay Toolset, viewed 30 March 2019, http://desktop.arcgis.com/ en/arcmap/10.3/tools/coverage-toolbox/union.htm

Environmental Systems Research Institute 2018, ArcGIS Desktop, version 10.6, computer software, Environmental Systems Research Institute, Redlands.

European Association for Coal and Lignite 2018, EURACOAL Market Report 1/2018, viewed 29 March 2019, http://euracoal2.org/download/Public-Archive/Library/Market-Reports/EURACOAL-Market-Report-2018-1_v10.pdf

Frantál, B 2016, 'Living on coal: Mined-out identity, community displacement and forming of anti-coal resistance in the Most region, Czech Republic', Resources Policy, vol. 49, pp. 385-393.

Geertz, C 1996, 'Afterword', in S Feld \& KH Basso (eds), Senses of Place, School of American Research Press, Santa Fe.

Geoportal CUZK 2019, WMS view service - ZM 25, viewed 3 June 2019, https://geoportal.cuzk.cz/ (S(jt05oyzw2msevkdglgbrcwuo))/Default.aspx?menu=3116\&mode=TextMeta\&side=wms.verejne\&metadatalD=CZ-CUZKWMS-ZM25-P\&metadataXSL=metadata.sluzba

Hendrychová, M \& Kabrna, M 2016, 'An analysis of 200-year-long changes in a landscape affected by large-scale surface coal mining: History, present and future', Applied Geography, vol. 74, pp. 151-159.

Ministry of Industry and Trade 2014, State Energy Policy of the Czech Republic, Prague, viewed 3 June 2019, https://www.mpo.cz/assets/en/energy/state-energy-policy/2017/11/State-Energy-Policy-_2015 EN.pdf

Owen, JR \& Kemp, D 2015, 'Mining-induced displacement and resettlement: A critical appraisal', Journal of Cleaner Production, vol. 87, pp. 478-488. 
Petrova, S \& Marinova, D 2013, 'Social impacts of mining: changes within the local social landscape', Rural Society, vol. 22, no. 2, pp. 153-165.

Říha, M, Stoklasa, J, Lafarová, M, Dejmal, I, Marek, J \& Pakosta, P 2005, Environmental Mining Limits in North Bohemian Lignite Region, Society for Landscape, Prague.

van der Plank, S, Walsh, B \& Behrens, P 2016, 'The expected impacts of mining: Stakeholder perceptions of a proposed mineral sands mine in rural Australia'. Resources Policy, vol. 48, pp129-136.

Zvarivadza, T 2018 'Large scale miners-Communities partnerships: A plausible option for communities survival beyond mine closure', Resources Policy, vol. 56, pp. 87-94. 